\title{
分散性混相流のハイブリッド数值計算手法の開発* (界面追跡法と流体粒子追跡法の統合)
}

\author{
迫田健 一*1, 冨山明男*2, 宋 明 良*2
}

\begin{abstract}
A Hybrid Method for the Prediction of Dispersed Multi-Phase Flows (Integration of Interface Tracking and Fluid-Particle Tracking Methods)
\end{abstract}

Kenichi SAKODA, Akio TOMIYAMA*3 and Akira SOU

${ }^{* 3}$ Department of Mechanical Engineering, Kobe University,

1-1 Rokkodai, Nada, Kobe-shi, Hyougo, 657-8501 Japan

\begin{abstract}
A hybrid numerical method for solving dispersed multi-phase flows was developed. The method is the integration of an interface tracking method (ITM) based on a volume tracking scheme, a new fluid particle tracking method (PTM) based on a one field formulation (OFPT), a PTM based on the jump condition (BCPT) and a PTM based on volume averaging (VAPT). This hybrid integration made it possible to cover a wide range of spatial resolution within the context of continuum dynamics. The validity of OFPT was confirmed through comparisons of predicted bubble wake velocity distributions between OFPT and ITM. It was also verified through a simulation of two inline air bubbles and that of air-water bubbly flow in a duct that OFPT can seamlessly connect to ITM.
\end{abstract}

Key Words : Numerical Analysis, Two-Phase Flow, Particle Tracking Method, Interface Tracking Method

\section{1. 腥言}

現在，様々な空間スケールに立脚する分散性混相流 のモデル化と数值計算技術の開発が進められている.

分散性混相流における素過程の物理的理解とモデル化 には, 分子動力学法(1) ・ボルツマン方程式等の統計力 学的手法 ${ }^{(2)}$ ，二相界面近傍境界層を捉えられる境界適 合格子法等の高空間分解能型界面追跡法(3)(4)等のミク ロからメゾ，マクロスケールにわたる計算技術が重要 な役割を果しつつある(5)。一方, 混相流を含む機器の 設計・開発においては，均質流モデル・多流体モデル (MFM: Multi-Fluid Model) ${ }^{(6)}$ 等の平均化された場の方程 式に基づく平均化手法，個々の気泡・液滴をラグラン ジュ的に追跡する流体粒子追跡法 (PTM: Particle Tracking Method) ${ }^{(7-12)}$ ，及び体積追跡法等に基づく比較 的低空間分解能の界面追跡法 (ITM: Interface Tracking Method) ${ }^{(13,14)}$ が, 対象とする問題に応じて使い分けられ ている.これら３種の手法は全てマクロスケール(連続 体のスケール)に立脚しているため統合化の可能性を 有しており, Tomiyama ら ${ }^{(15)}$ は MFM と ITM を統合し たハイブリッド手法を既に提示している. 図 1 に3 種 の手法が扱える空間スケールを模式的に示す. 図中の $d^{*}$ は, 次式で定義される分散流体粒子の無次元直径を

* 原稿受付 2005 年 3 月 14 日.

*1 正員, 神戸大学大学院自然科学研究科(亚657-8501 神戸市 灘区六甲台町 1-1)

*2 正員, 神戸大学工学部.

E-mail : tomiyama@mech.kobe-u.ac.jp
意味する.

$d^{*}=\frac{d}{\Delta x}$

ここで， $d$ は流体粒子代表直径， $\Delta x$ は計算格子サイズ を表す．MFM は格子サイズに比べ小さな流体粒子が 多数含まれる流れ，すなわち $d^{*}<1$ の計算に適してお り, ITM は $d^{*}>10$ 程度の大きな流体粒子の計算に適 している.このため, MFM とITMの統合化手法によ り $1<d^{*}<10$ 程度の空間分解能の計算を行うためには, 数密度輸送方程式の導入などの特殊な工夫が必要とな $3^{(16)}$. 一方, PTM は $d^{*}<4$ 程度の計算に適しており， MFM と ITM ではカバーできない空間分解能を一部補 っている. 従って, ITM, PTM, MFM を統合化すれば, マクロスケールの範囲内で様々な大きさの粒子を含む 分散性混相流を扱える手法となりえる. 本研究では, 上記統合手法開発の第一段階として，PTM と ITM の 統合化を目的とした. 既存の PTM の多く ${ }^{(7,8)}$ は $d^{*}<1$ の小粒子しか极えないのに対し，冨山らは $d^{*} \leq 2$ の流 体粒子を扱える体積平均に基づく手法 (VAPT: Volume

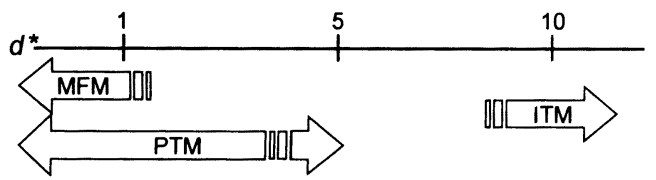

Fig.1 Spatial resolutions of MFM, PTM and ITM 
Averaging PT) ${ }^{(9,10)}$ と, 流体粒子界面に速度境界条件を 与えることによって $2<d^{*}<4$ 程度の流体粒子を扱え る手法 (BCPT: Boundary Condition PT) ${ }^{(1)}$ を提案してい る. しかし, $4 \leq d^{*}<10$ 程度を適正に扱える PTM は見 受けられず, ITMで扱える $d^{*}$ との間に隙間が残る. ま た, BCPT では流体粒子内部の流れが求められないた め, 仮に BCPT と ITM を統合した場合, 気泡合体など により計算手法を BCPTからITMに切り替える必要が 生じた際に, 流体粒子内部の速度や圧力を BCPT から ITMに受け渡すことができない.このため, 計算手法 切り替え時に計算の不安定化や計算効率低下が生じう る. これらの ITM-PTM 統合化における課題を克服す るためには，流体粒子内部の流れを適正に評価でき，

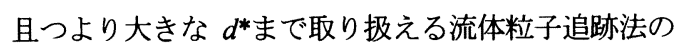
開発と $d^{*}<10$ でも良好な予測が可能な ITM の開発が

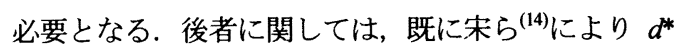
が 6 程度でも良好な予測が可能な体積追跡型界面追跡 法 ASCA (Advanced Subgrid Counting Algorithm)が提案 されている. そこで本研究では, ITM(ASCA)との円滑 な接合を可能とする一流体近似 (One Field Approximation)に基づく流体粒子追跡法 OFPT を開発 し，PTM と ITM が扱える $d^{*}$ 範囲の隙間を除去した八 イブリッド手法を構築した.

\section{2. 計算手法}

$2 \cdot 1$ OFPT の概要 まずハイブリッド手法に組 み込む OFPT の概要を示寸. 詳細については, ハイブ リッド手法の説明の際に述べる. OFPT は, ITM と同 一の一流体近似に基づく質量・運動量保存式,

$\nabla \cdot \boldsymbol{u}=0$

$\frac{\partial \boldsymbol{u}}{\partial \boldsymbol{t}}+\boldsymbol{u} \cdot \nabla \boldsymbol{u}=-\frac{1}{\rho_{O F}} \nabla P+\boldsymbol{g}+\frac{\boldsymbol{F}_{\mu}+\boldsymbol{F}_{S}}{\rho_{O F}}$

を用いる.ここで, $t$ は時間, $\boldsymbol{u}$ は一流体近似混合相の 速度, $P$ は圧力, $g$ は重力加速度, $\rho_{O F}$ は一流体近似混 合相密度(定義は後述の式(10)), $\boldsymbol{F}_{\boldsymbol{\mu}}$ は粘性拡散, $\boldsymbol{F}_{S}$ は表 面張力を表す. ITM と OFPT の相違点は, 流体粒子の 体積率輸送方法にある. 体積追跡法に基づく ITM では 流体粒子体積の輸送は次式を用いて計算される.

$\frac{\partial \alpha_{p}}{\partial t}+\boldsymbol{u} \cdot \nabla \alpha_{p}=0$

ここで $\alpha_{p}$ は流体粒子の体積率である. 一方, OFPT の 流体粒子は， $i$ 番目の流体粒子に対する以下の運動方 程式を用いて, 流体粒子の変形を考虑せずにラグラン
ジュ的に追跡する.

$\left(\rho_{p}+C_{V} \rho_{c}\right) \frac{d V^{i}}{d t}=\left(1+C_{V}\right) \rho_{c} \frac{d u}{d t}+\left(\rho_{p}-\rho_{c}\right) g-f_{\text {int }}^{i}$

ここで， $\rho_{p}, \rho_{c}$ は各々流体粒子・連続相の密度， $C_{V}$ は 仮想質量係数, $V$ は流体粒子速度, $f_{\text {int }}$ は流体粒子に働 く抗力, 揚力等の相間相互作用力である. 式(2),(3),(5) より, ITM と同様に界面境界条件を考慮しつつ, 流体 粒子内外の流れ場を求めることが可能となる.

2.2 ハイブリッド手法の基礎式 図 2(a)に本研 究で提案するハイブリッド手法の概念図を示す. 本手 法では ITM, OFPT, BCPT, VAPT の 4 種の計算手法を統 合する. 具体的には図 2(a)に示すように $d^{*}>8$ 程度の 計算セルより十分大きい流体粒子は ITM, $4 \leq d^{*} \leq 8$ 程 度では OFPT, $2<d^{*}<4$ 程度の流体粒子は BCPT, $d^{*} \leq$ 2 ではVAPT により計算する. 本手法は気泡や液滴な ど任意の分散流体粒子を含む混相流に適用できるが， 以下では気液二相気泡流を例に本手法を説明する. 本 手法は 4 種の計算手法を含むため, 計算セルには図 2(b)に示すように最大 5 種の体積率が存在しうる. 図 中, $\alpha$ は体積率, 添字 $L$ は液相, $G 1$ は ITM で扱う気 相, $G 2$ は OFPT で扱う気泡, $G 3$ は BCPT で扱う気泡, $G 4$ は VAPT で扱う気泡を表す. 従って, 各相体積率 は次式を満足する.

$\alpha_{L}+\alpha_{G 1}+\alpha_{G 2}+\alpha_{G 3}+\alpha_{G 4}=1$

ここで, 一流体近似を ITM 及び OFPT で扱う気泡, 液 相の 3 つに適用する. これらの混合体の体積率 $\alpha_{O F}$ を 次式で定義する.

$\alpha_{O F}=\alpha_{L}+\alpha_{G 1}+\alpha_{G 2}$

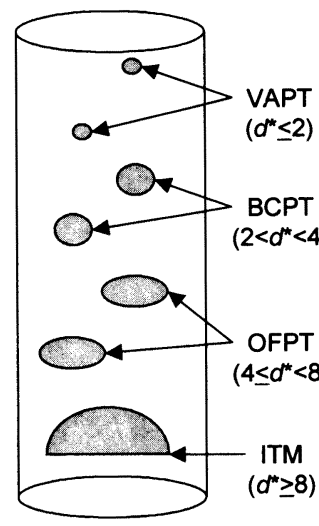

(a) $d^{*}$ - dependent strategy

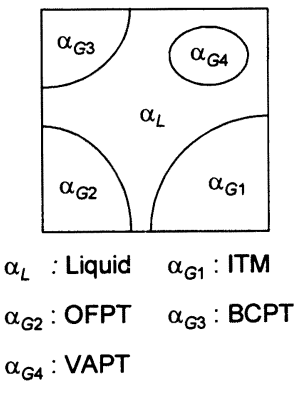

(b) Volume fractions
Fig.2 Concept of the hybrid fluid-particle tracking method 
ここで，添字 $O F$ は一流体近似混合相を表す，各相と も物性值が一定な非圧縮性ニュートン流体と仮定する と, 混合相に対する一流体近似質量・運動量保存式は 次式で与えられる.

$\nabla \cdot\left(\alpha_{O F} u\right)=\frac{\partial\left(\alpha_{G 3}+\alpha_{G 4}\right)}{\partial t}$

$\frac{\partial \boldsymbol{u}}{\partial t}+\boldsymbol{u} \cdot \nabla \boldsymbol{u}=-\frac{1}{\rho_{O F}} \nabla P+\boldsymbol{g}+\frac{\boldsymbol{F}_{\mu}+\xi \boldsymbol{F}_{S}+\eta \boldsymbol{F}_{G 4}}{\alpha_{O F} \rho_{O F}}$

ここで, $\rho_{O F}, \boldsymbol{F}_{\mu}, \boldsymbol{F}_{S}$ は各々以下の諸式で定義する.

$\rho_{O F}=\frac{\left(\alpha_{G 1}+\alpha_{G 2}\right) \rho_{G}+\alpha_{L} \rho_{L}}{\alpha_{O F}}$

$\boldsymbol{F}_{\mu}=\nabla \cdot\left\{\frac{\left(\alpha_{G 1}+\alpha_{G 2}+\alpha_{L}\right)^{2} \mu_{L} \mu_{G}}{\left(\alpha_{G 1}+\alpha_{G 2}\right) \mu_{L}+\alpha_{L} \mu_{G}}\left[\nabla \boldsymbol{u}+(\nabla \boldsymbol{u})^{T}\right]\right\}$

$\boldsymbol{F}_{S}=\alpha_{O F} \sigma \kappa \delta_{S} \boldsymbol{n}_{S}$

また, $\boldsymbol{F}_{G 4}$ はVAPT で扱う気泡と液相との単位体積当 りの気液間相互作用項を表し，次式で評価する.

$\boldsymbol{F}_{G 4}=\alpha_{G 4} C_{V} \rho_{L}\left(\frac{d \boldsymbol{u}_{G 4}}{d t}-\frac{d \boldsymbol{u}}{d t}\right)+\boldsymbol{M}_{D}+\boldsymbol{M}_{L F}+\boldsymbol{M}_{G L}$

式(11)-(13)において, $\mu$ は粘性係数, $\sigma$ は表面張力, $\kappa$ は界面の曲率, $\delta_{S}$ は界面以外で 0 となるデル夕関数,

$n_{S}$ は界面の単位法線ベクトル, $\boldsymbol{u}_{G 4}$ は VAPT で扱う気 泡の相平均速度べクトル, $\boldsymbol{M}_{D}, \boldsymbol{M}_{L F}, \boldsymbol{M}_{G L}$ は各々単位体 積当たりの気泡に働く抗力, 揚力, その他の気液間作 用力の反作用力を意味する. 上付添字 $T$ は転置を表す. 本報では， $\boldsymbol{F}_{S}$ を CSF (Continuum Surface Force) モデル (17)を用いて評価する. 式(13)の dldt は次式で定義され る実質微分を意味する.

$\frac{d \boldsymbol{u}_{G 4}}{d t}=\frac{\partial \boldsymbol{u}_{G 4}}{\partial t}+\boldsymbol{u}_{G 4} \cdot \nabla \boldsymbol{u}_{G 4}$

$\frac{d \boldsymbol{u}}{d t}=\frac{\partial \boldsymbol{u}}{\partial t}+\boldsymbol{u} \cdot \nabla \boldsymbol{u}$

運動量保存式(9)に含まれる 2 つの変数, , 法に応じて適切な気液間相互作用力を与えるために導 入したパラメーターである. 表面張力は ITM で扱う気 相及びOFPT で扱う気泡の界面において考慮する. 従 って $\alpha_{G 1}+\alpha_{G 2}>0$ の計算セルでは $\xi=1$ とし, それ以外 のセルでは 0 とする. 気液間相互作用力は, ITM と
OFPT では一流体近似により, BCPT では気液界面速 度境界条件により自動的に考慮される. 従って $\alpha_{64}>0$ の計算セルでは $\eta=1$ とし, それ以外のセルでは $=0$

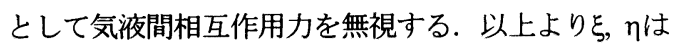
次式で与えられる.

$\xi= \begin{cases}1 & \text { when } \alpha_{G 1}+\alpha_{G 2}>0 \text { in a cell } \\ 0 & \text { otherwise }\end{cases}$

$\eta= \begin{cases}1 & \text { when } \alpha_{G 4}>0 \text { in a cell } \\ 0 & \text { otherwise }\end{cases}$

次に, 各種気相の計算方法について述べる.まずITM で扱う気相の体積率 $\alpha_{G 1}$ は次式で輸送する.

$\frac{\partial \alpha_{G 1}}{\partial t}+\boldsymbol{u} \cdot \nabla \alpha_{G 1}=0$

本報では，ASCA を用いて式(18)を計算する.

OFPT, BCPT, VAPT で扱う気泡は, 各々ラグラン ジュ的に追跡する. $i$ 番目の気泡に対して次の運動方 程式が成り立つ.

$$
\begin{aligned}
\left(\rho_{G}+C_{V} \rho_{L}\right) \frac{d V^{i}}{d t}=\left(1+C_{V}\right) \rho_{L} & \frac{d u}{d t}+\left(\rho_{G}-\rho_{m}\right) g \\
& -f_{D}^{l}-f_{L F}^{l}-f_{G L}^{l}
\end{aligned}
$$

ここで, $f_{D}, f_{L F}, f_{G L}$ は気泡に働く抗力, 揚力, その 他の気液間相互作用力である. 気泡運動が壁の影響を 受ける場合には壁力，気泡が摇動運動をする場合には

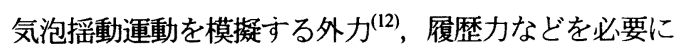
応じて $\boldsymbol{f}_{G L}$ に適用すれば良い. $\rho_{\mathrm{m}}$ は次式で定義する.

$\rho_{m}=\rho_{G} \sum_{n=1}^{4} \alpha_{G n}+\rho_{L} \alpha_{L}$

$\rho_{\mathrm{m}}$ を評価する検査体積は, 気泡径 $d$ の気泡の重心を中 心とした $(2 d) \times(2 d) \times(2 d)$ の立方体とした ${ }^{(11)}$.

以上, 式(6)-(20)が本研究で提案する ITM と PTM の ハイブリッド手法の基礎式である. なお， $\alpha_{G 2}=\alpha_{G 3}=$ $\alpha_{G 4}=0$ の場合, 本手法の基礎式はITM の基礎式と同 一となり, $\alpha_{G 1}=\alpha_{G 2}=0$ の場合, 既存の PTM ${ }^{(11)}$ の基礎 式と同一となる. また, $\alpha_{G 1}=\alpha_{G 3}=\alpha_{G 4}=0$ の場合, 本 手法の基礎式は OFPT の基礎式となる.

$2 \cdot 3$ 気液間相互作用 VAPT で扱う気泡と液相 間の相互作用を考慮するためには, 式(19)内の $\boldsymbol{f}$ と式 (13)内の $\boldsymbol{M}$ を対応付ける関係式が必要となる. 本関倸 式には，体積平均の定義に基づく次式を用いる(9,10). 
$\boldsymbol{M}=\frac{1}{\theta_{l m n}} \sum_{i=1}^{N} \gamma_{l m n}^{i} \theta^{i} \boldsymbol{f}$

ここで, 添字 $l, m, n$ は非負整数で座標 $(l \Delta x, m \Delta y, n \Delta z)$ に 位置する計算セルを表す。 $\theta_{l m n}$ は計算セル体積, $N$ は 全計算領域に含まれる VAPT で扱う気泡の総数, $\theta^{\prime}$ は $i$ 番目の気泡の体積, $\gamma_{l m n}^{i}$ はセル $(l, m, n)$ に含まれる $i$ 番 目の気泡の体積割合である. 同様にして, セル $(l, m, n)$ における気相体積率 $\alpha_{G 4}$, 相平均速度, 相平均加速度は 以下の諸式で計算する.

$\alpha_{G 4 l m n}=\frac{1}{\theta_{l m n}} \sum_{i=1}^{N} \gamma_{l m n}^{\prime} \theta^{\prime}$

$\boldsymbol{u}_{G 4 l m n}=\frac{1}{\alpha_{G 4 l m n} \theta_{l m n}} \sum_{i=1}^{N} \gamma_{l m n}^{i} \theta^{i} \boldsymbol{V}^{i}$

$\left(\frac{d \boldsymbol{u}_{G 4}}{d t}\right)_{l m n}=\frac{1}{\alpha_{G 4 l m n} \theta_{l m n}} \sum_{i=1}^{N} \gamma_{l m n}^{\prime} \theta^{i} \frac{d \boldsymbol{V}^{\prime}}{d t}$

ここで, $\gamma_{l m n}^{\prime}$ は気泡の重心位置・形状から求められる.

なお, BCPT, OFPT の気相体積率 $\alpha_{G 2}, \alpha_{G 3}$ は気泡形状 を回転楕円体等で近似し数值積分を用いて計算する.

BCPT では, 式(17)に示したように抗力, 揚力等の反 作用力を無視し, 気液界面に境界条件を与えることで 気泡運動が液相に与える影響を考慮する. 気液界面境 界条件としては，例えば界面活性剂の吸着による弱い マランゴニ効果を模擬する場合は, 気泡の前面では滑 り壁条件, 気泡の後面では滑りなし条件を与える. 気 液界面境界条件の設定方法については文献(11)を参照 されたい. OFPT およびITM では，一流体近似により 気液間相互作用は自動的に考慮される.

$2 \cdot 4$ 計算手順図 3 に本手法の計算手順の概略 を示す．図中の $n$ は離散時間 $t^{n}=n \Delta t$ を表す。

まず, $n=0$ における気泡位置, 気泡速度, 液相速度 分布, 圧力分布等の初期条件を与える. 気泡追跡, 混 合相, 界面追跡の順に終了時刻まで計算を繰り返す. 気泡追跡計算では，VAPT， BCPT， OFPT で扱う各気 泡の新しい時刻における速度 $\boldsymbol{V}^{n+1}$, 位置 $\boldsymbol{x}^{\prime n+1}$ を各々 式(19), $x^{n+1}=x^{j n}+V^{i n+1} \Delta t$ を用いて計算する. 混合相計 算では，式(21)-(24)を用いて $\alpha_{G 2}{ }^{n+1}, \alpha_{G 3}{ }^{n+1}, \alpha_{G 4}{ }^{n+1}, \boldsymbol{M}$, $d \boldsymbol{u}_{G} d d t$ を求めた後, 気液界面での速度境界条件, 表面 張力項を考虑した式(8)，(9)を解き，一流体近似混合相 の新しい時刻における速度 $\boldsymbol{u}^{n+1}$, 圧力 $P^{n+1}$ を求める. その後, 式(18)を解き $\alpha_{G 1}{ }^{n+1}$ を求める.

2.5 權成式·相関式 次節の計算で使用する構成 式・相関式を整理しておく.抗力 $\boldsymbol{f}_{D} に$ に次式を用いる.

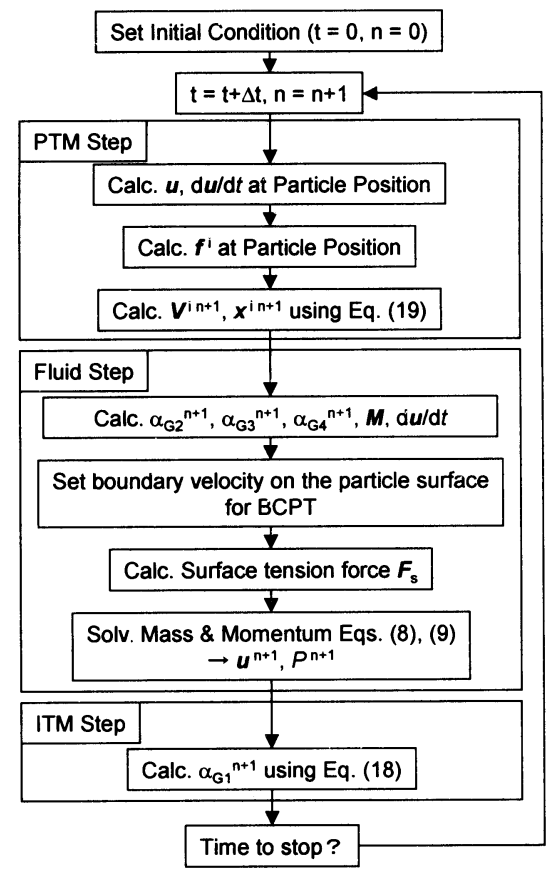

Fig.3 Outline of solution procedure

$\boldsymbol{f}_{D}^{i}=\frac{3}{4 d^{i}} C_{D}^{i} \rho_{L}\left|V^{i}-u\right|\left(V^{i}-u\right)$

ここで, 抗力係数 $C_{D}$ には, 低粘性で表面張力が支配 的な条件 ${ }^{(18)}$ では次式を用いる.

$C_{D}= \begin{cases}\frac{8}{3} \frac{E o}{E^{2 / 3}\left(1-E^{2}\right)^{-1} E o+16 E^{4 / 3}} F(E)^{-2} & \text { for } E<1 \\ \frac{8}{3} \frac{E o}{E^{2 / 3}\left(E^{2}-1\right)^{-1} E o-16 E^{4 / 3}} G(E)^{-2} & \text { for } E>1\end{cases}$

$F(E)=\frac{\sin ^{-1} \sqrt{1-E^{2}}-E \sqrt{1-E^{2}}}{1-E^{2}}$

$G(E)=\frac{E \sqrt{E^{2}-1}-\tanh ^{-1}\left(\sqrt{E^{2}-1} / E\right)}{E^{2}-1}$

ここで, $E$ は気泡アスペクト比(短軸長/長軸長), $R e, E o$ は次式で定義される気泡レイノルズ数, エトベス数で ある。

$R e=\frac{\rho_{L}|\boldsymbol{V}-\boldsymbol{u}| d}{\mu_{L}}$ 
$E o=\frac{g\left(\rho_{L}-\rho_{G}\right) d^{2}}{\sigma}$

粘性力が支配的な条件では次式を用いる(19).

$C_{D}=\min \left[\frac{16}{R e}\left(1+0.15 R e^{0.687}\right), \frac{48}{R e}\right]$

揚力 $f_{L F}$ には次式を用いる.

$f_{L F}^{i}=C_{L F}^{i} \rho_{L}\left(V^{i}-u\right) \times(\nabla \times u)$

上式中の揚力保数 $C_{L F}$ には次式(20)を用いる.

$C_{L F}= \begin{cases}\min \left[0.288 \tanh (0.121 R e), \varphi\left(E o_{d}\right)\right],\left(E o_{d}<4\right) \\ \varphi\left(E o_{d}\right), & \left(4<E o_{d}<10.7\right)\end{cases}$

$\varphi(x)=0.00105 x^{3}-0.0159 x^{2}-0.0204 x+0.474$

ここで, $E o_{d}$ は代表長さに気泡の水平方向長さ $a$ を用 いた修正エトベス数である.

水中の空気泡 $(d>1.3 \mathrm{~mm})$ は, ヘリカル, ジグザグ, ロッキング等様々な摇動運動を呈しながら上昇する.

本報では，このような気泡の摇動運動を模擬する際に は, 以下の摇動運動誘起力 $f_{f}$ をその他の気液間相互作 用力 $f_{G L}$ として使用する ${ }^{(12)}$.

$f_{f}=\left(\rho_{G}+C_{V} \rho_{L}\right) s \omega^{2}\left(\sin \omega t e_{1}+\cos \omega t e_{2}\right)$

ここで, $\boldsymbol{e}_{1}, \boldsymbol{e}_{2}$ は水平面内の互いに直交する単位ベクト ル, $s$ は摇動運動の振幅, $\omega$ は角速度である. ヘリカル 運動の場合は $e_{2}$ は正の值を与えるが，ジグザグ運動の 場合は $e_{2}=0$ とする.

\section{3. 検証計算}

3.1 OFPTの検証 OFPT の妥当性を検証するた めに, OFPT による高粘度静止液相中単一気泡の後流 速度分布計算結果を ITM による計算結果と比較する. 図 4 に計算体系と境界条件を示す，上部境界は連続条 件とし，他の境界はすべり壁とした，計算領域は $4 d$ $\times 4 d \times 10 d$ とした，空間分解能はITM， OFPT の計算 共に $d^{*}=8$ とした. 各相物性値は一定とし, $\log M=-2.8$ とした.ここでMは以下のモルトン数である.

$M=\frac{g \mu_{L}^{4}\left(\rho_{L}-\rho_{G}\right)}{\sigma^{3} \rho_{L}^{2}}$

また, エトベス数 $E o$ は回転楕円体形から冠球形の気 泡形状の条件を含む $E O=5,10,20$ の 3 条件とした. な

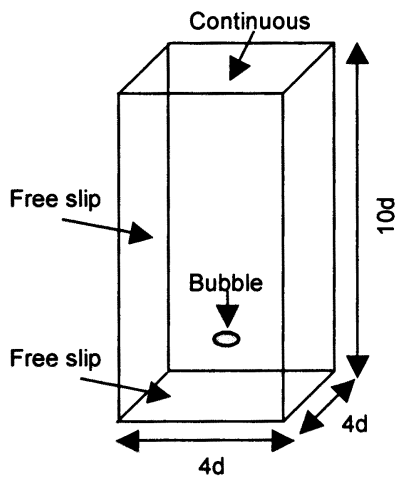

Fig.4 Initial and boundary conditions

お，OFPTで用いる気泡形状にはITM で得られた最終 的な気泡形状を模擬したものを用いた.

気泡中心断面速度場と気泡界面形状の計算結果を図 5 に示す．各条件とも左側が ITM，右側が OFPT であ る. OFPT では一流体近似により気泡内部の流れ場も 解かれており ITM とよく一致している。

気泡後流域における気泡中心軸上の鉛直方向速度成 分 $V_{L}$ の分布を図 6 に示す. $V_{L}$ は気泡下端の速度 $V_{\mathrm{T}}$ を 用いて規格化してある. 横軸の無次元座標 $-z / d$ は気泡 下端位置の鈆直座標 $z$ を基隻值 0 としている. OFPT による気泡後流速度計算結果は, ITMによる結果と良 好に一致している. 本結果より, 気泡形状を正しく与 えれば, OFPTにより気泡内部も含めて ITM と同等の 計算結果を得られることが確認できた.

$3 \cdot 2$ 各種 PTM の適用空間分解能の検討 図 2(a) に示したようにハイブリッド手法では $d^{*}$ の值に応じ て異なる計算手法, すなわち $d^{*} \leq 2$ ではVAPT, $2<d^{*}$ $<4$ では BCPT, $4 \leq d^{*}<8$ では OFPT, $d^{*} \geq 8$ では ITM を使用する. この $d^{*}$ 值に基づく手法の切り替えの妥当 性を検討するために，前節に示した静止液中単一気泡 計算 $(E O=5)$ を $2 \leq d^{*} \leq 8$ の範囲で行った. 図 7 に気泡 後流速度分布計算結果を示す. 計算の空間分解能・計 算手法が異なるため気泡值下では各手法により多少の 相違は見られるが, 後流速度减衰過程は良好に一致し ている. 本結果より，前述の $d^{*}$ 值に基づく計算手法の 切り替えの妥当性, 及び 3 種の流体粒子追跡法と界面 追跡法の組み合わせにより，全ての空間分解能 $\left(d^{*}>0\right)$ を網羅できることを確認できた，従って， $d^{*}$ の值に応 じて VAPT, BCPT, OFPT, ITM の中から適切な手法 を選択することによって，気泡運動が液相に及ぼす影 響を予測できる.

3.3 OFPT とITM間の切り替え OFPTは $4 \leq d^{*}$ $\leq 8$ の範囲を網羅する役割と, PTM と ITM 間の切り替 


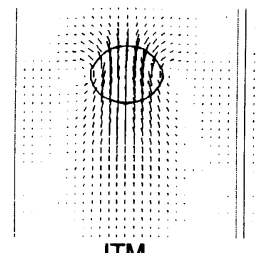

ITM

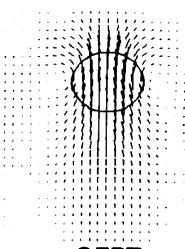

OFPT

(a) $E o=5$

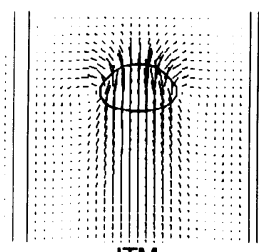

ITM

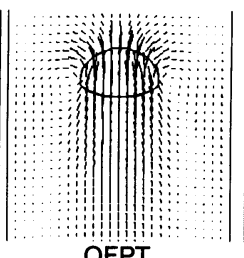

OFPT

(b) $E o=10$

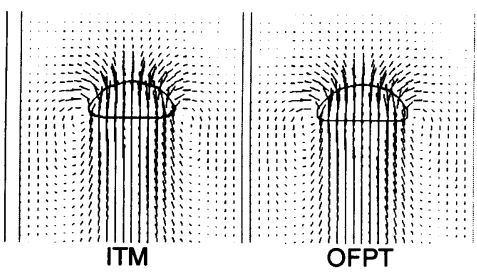

(c) $E o=20$

Fig.5 Velocity fields calculated by ITM and OFPT

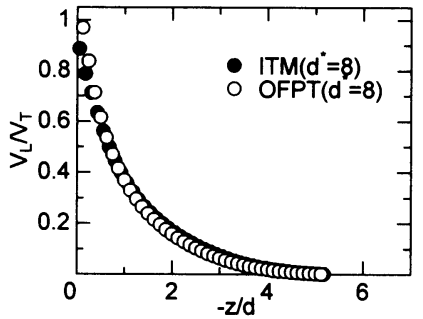

(a) $E o=5$

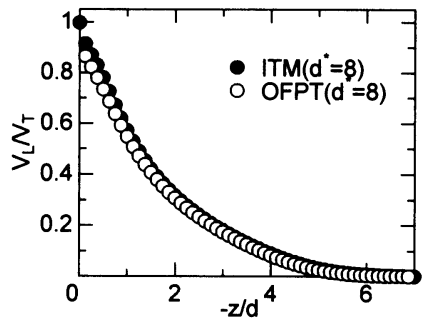

(b) $E o=10$

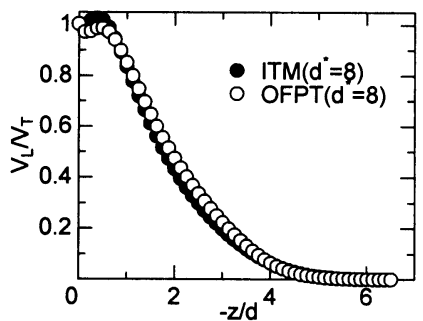

(c) $E o=20$

Fig.6 Wake velocity distributions calculated by ITM and OFPT

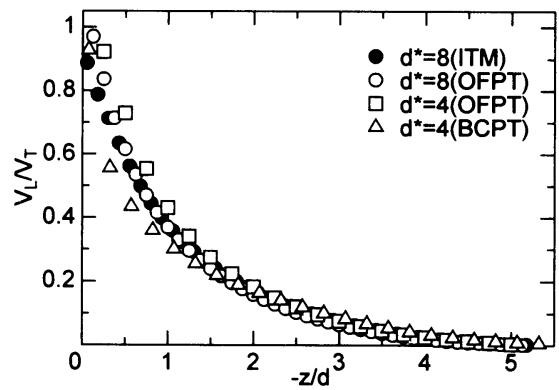

(a) ITM, OFPT and BCPT

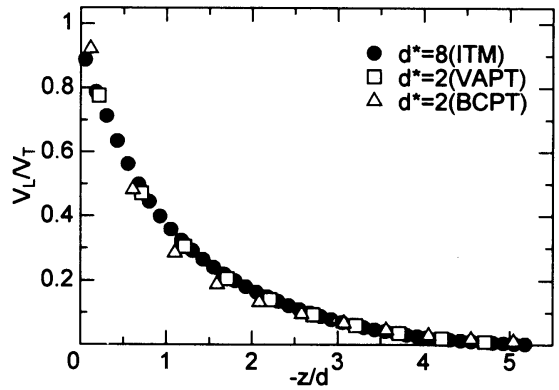

(b) ITM, VAPT and BCPT

Fig.7 Wake velocity distributions calculated by the four methods

えを円滑にする役割を受け持つ. 以下，後者について 検証する. ハイブリッド手法による無限静止水中直列 2 気泡の計算結果を図 8 に示す．流体物性は常温常圧 の水・空気系の值, セルサイズは $1 \mathrm{~mm}$, 気泡径は $8 \mathrm{~mm}$ $\left(d^{*}=8\right)$ とした. 気泡を計算領域内に保持するために, 上部境界から気泡終端上昇速度で液相を一様流下させ

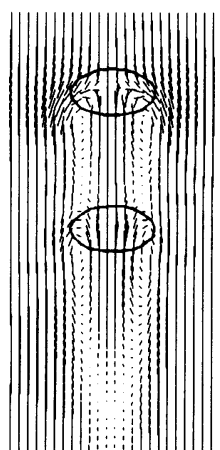

OFPT

$t=0.157 \mathrm{sec}$

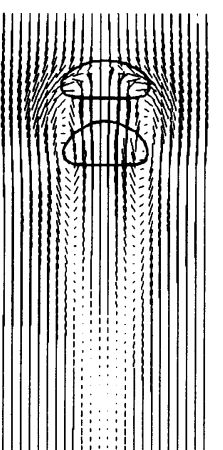

Switched to ITM $t=0.200 \mathrm{sec}$

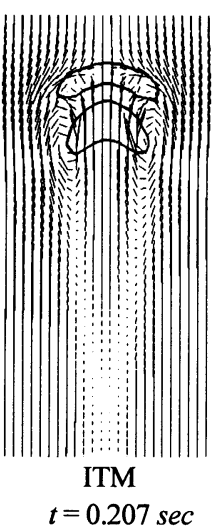

Fig.8 Hybrid simulation of two inline bubbles in a stagnant water at atmospheric pressure and room temperature

ている. 本計算では，揚力・摇動誘起力等の横方向力 は無視した. 計算初期では両気泡は共に OFPT で計算 されている. 気泡後流により後続気泡と先行気泡の気 泡間距離が小さくなると, 気泡の変形が重要となる.

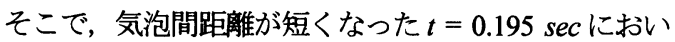
て, 計算アルゴリズムを OFPTから ITMへ切り替えた. OFPT は一流体近似を用いているため, 気泡内部の流 れ場も計算されている. このため, 切り替え直後も速 度場と圧力場はスムーズに接合した。

3.4 ハイブリッド計算例図 9 に, 幅 $30 \mathrm{~mm}$, 高 さ $100 \mathrm{~mm}$ の正方形ダクト内水・空気系気泡流の計算 例を示す. セルサイズは $1 \mathrm{~mm}$ とし, 上部境界から液 相を一定速度で流下させ, 気泡を計算領域に保持して いる. 小気泡 $\left(d^{*}=2\right)$, 中気泡 $\left(4 \leq d^{*}<8\right)$ 及び大気泡 $\left(d^{*}\right.$ 
～8)の計算には, 各々VAPT, OFPT, ITMを用いてい る. 大気泡と他の気泡の合体は，気泡間距離が小さく なった場合, 計算手法をITMに切り替えることで考慮 した. また, PTM の気泡同士では, 気泡が接触した際, 必ず合体するとした. その際, 合体後の気泡が $d^{*} \geq 8$ となる場合は両気泡を ITM に切り替え, $d^{*}<8$ となる 場合は先行気泡の位置に合体後の気泡を置いた. $t=$ $0.20 \mathrm{sec}$ において, ITM で計算されている大気泡は, 計算体系中央に存在する 1 つのみである. しかし, $t=$ $0.28 \mathrm{sec}$ での流れ場では，中気泡同士が合体し， $d^{*} \geq 8$ となったためにITM で計算される気泡が2つになって いる.このような大小様々な気泡が存在する気泡流を ITMのみで計算する場合, 小気泡に多数の計算セルを 割り当てねばならず莫大な記憶容量と計算時間が必要 となるが，ハイブリッド手法では標準的 PC を用いて 計算できる (総計算セル数 90000 の図 9 の計算では, $t$ $=1.0 \mathrm{sec}$ までの計算に標準的 PC(CPU: Pentium IV, $3.0 \mathrm{GHz}$ )で約 48 時間を要した).

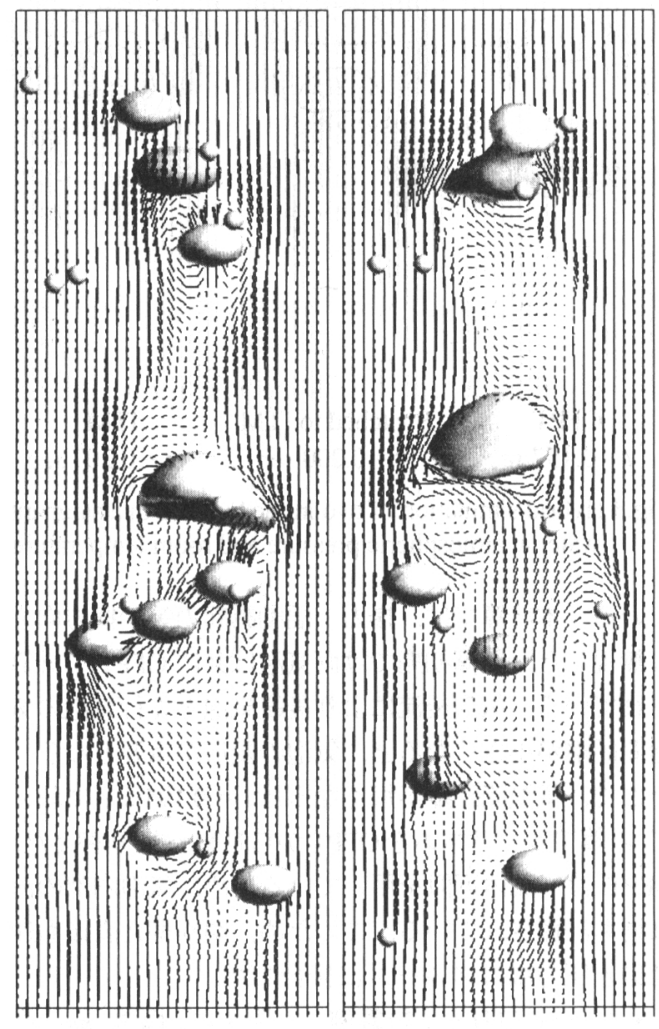
(a) $t=0.20 \mathrm{sec}$
(b) $t=0.28 \mathrm{sec}$

Fig.9 Hybrid simulation of air-water bubbly flow in a duct

\section{4. 結言}

本研究では, 様々な空間スケールに立脚する分散性 混相流の統合計算手法構築の第一段階として, 界面追 跡法(ITM) と 3 種の流体粒子追跡法(PTM)を組み合わせ たハイブリッド粒子追跡法を構築し, 以下の結論を得 た.

(1) 流体粒子の直径当りに割り当てるセル数 $d^{*} \leq 2$ の 場合は VAPT, $2<d^{*}<4$ の場合は BCPT, $4 \leq d^{*}<8$ の 場合は OFPT, $8 \leq d *$ の場合は ITM を適用すること によって，全ての $d^{*}$ を網羅できることを確認した．

（2）一流体近似に基づく新たな粒子追跡法 OFPT は, 粒子形状を適切に与えれば流体粒子内外の流れ場 を良好に計算できる。

（3）気泡合体等により OFPTから ITMに切り替える必 要が生じた際でも，円滑に計算手法を切り替えら れることを確認した.

\section{謝辞}

本研究は平成 15,16 年度科学研究費補助金基盤研究 (B)(2)(15360095)の助成を受けて実施したものである.

\section{文献}

(1) Park, S. H., Weng, J. G. and Tien, C. L., "A Molecular Dynamics Study on Surface Tension of Microbubbles", Int. J. Heat and Mass Transfer, 44, (2001), p. 1849-1856.

(2) Takada, N., Misawa, M., Tomiyama, A. and Fujiwara, S., "Numerical Simulation of Two- and Three-dimensional Two-Phase Fluid Motion by Lattice Boltzmann Method", Comp. Physics Communications, 129, (2000), pp.233-246.

(3) Ryskin, G. and Leal, L. G., "Numerical Solution of Free-Boundary Problems in Fluid Mechanics. Part 1. The Finite-Difference Technique", $J$. Fluid Mech., 148, (1984), pp.1-18.

(4) Takagi, S., Matsumoto, Y. and Huang H., "Numerical Analysis of a Single Rising Bubble Using Boundary-Fitted Coordinate System", JSME Int. J., Ser. B, 40, (1997), pp.42-50

(5) Mougin, G. and Magnaudet, J., "The Generalized Kirchhoff Equations and their Application to the Interaction between a Rigid Body and an Arbitrary Time-Dependent Viscous Flow", Int. J. Multiphase Flow, 28, (2002), pp.1837-1851.

(6) Tomiyama, A. and Shimada, N., "A Numerical Method for Bubbly Flow Simulation based on a Multi-Fluid Model", Trans. ASME. J. of Pressure Vessel Technology, 123, (2001), pp.510-516.

(7) Murai, Y. and Matsumoto, Y., "Numerical Simulation of Turbulent Bubble Plumes using Eulerian-Lagrangian Bubbly Flow Model Equations", Proc. ASME FED. 1, FED-Vol.236, (1996), pp.67-74.

(8) Lain, S., Bröder, D., Sommerfeld, M. and Göz, M. F., "Modeling Hydrodynamics and Turbulence in a Bubble Column using the EulerLagrange Procedure", Int. J. Multiphase Flow, 28, (2002), pp. 1381-1407.

（9）富山・檜垣・Zun・宋・坂口, “粒子追跡法に基づく分散性混相流の 数值解析 (第 1 報, 数值解法と鉛直管内層流気泡流一の適用)”, 機 論 (B 編), 62-599, (1996), pp.2558-2564. 
(10)Tomiyama, A., Zun, I., Higaki, H., Makino, Y. and Sakaguchi, T., "A Three-Dimensional Particle Tracking Method for Bubbly Flow Simulation", Nucl. Eng. Des., 175, (1997), pp.77-86.

(11)Tomiyama, A., Makino, Y. and Zun, I., "Bubble Tracking Simulation of Interaction among Bubbles in a Bubbly Flow", Moving Boundaries $V$. WIT Press, (1999), pp.171-180.

(12) Tomiyama, A., Sakoda K. and Takada, N., "Two-Way Bubble Tracking Simulation of Void Wave Generation in a Bubbly Pipe Flow", Comp. Fluid Dynamics, J., 12, (2003), pp.482-490.

(13) Tomiyama, A., Zum, I., Sou, A. and Sakaguchi, T., "Numerical Analysis of Bubble Motion with the VOF Method", Nucl. Eng. Des., 141, (1993), pp.69-82.

(14) 宋・林・富山, “界面を含む流れの体積追跡法”, 機論(B 編), 70 - 698, (2004), pp.2538-2544.

(15) Tomiyama, A. and Shimada N., "(N+2)-Field Modeling for Bubbly Flow Simulation", Comp. Fluid Dynamics J., 9, (2001), pp.418-426.
(16) Tomiyama, A., Shimada N. and Asano, H., "Application of Number Density Transport Equation for the Recovery of Consistency in Multi-Field Model", on CD-ROM of ASME FEDSM, FEDSM200345168 (2003), pp.1-7.

(17) Brackbill, J. U., Kothe, D. and Zemach, C., "A Continuum Method for Modeling of Surface Tension”, J. Comp. Phys., 100, (1992), pp.335-354.

(18) Tomiyama A., Celata, G. P., Hosokawa, S. and Yoshida, S., "Terminal Velocity of Single Bubbles in Surface Tension Force Dominant Regime", Int. J. Multiphase Flow, 28, (2002), pp.1497-1519.

(19) Tomiyama, A., Kataoka, I., Zun, I. and Sakaguchi, T., "Drag Coefficients of Single Bubbles under Normal and Micro Gravity Conditions", JSME. Int., J., Ser. B., 41, 2, (1998), pp.472-479.

(20) Tomiyama, A., Tamai, H., Zun, I. and Hosokawa, S., "Transverse Migration of Single Bubbles in Simple Shear Flows", Chem. Eng. Sci., 57, (2002), pp.1849-1858. 